\title{
NATURALIZATION OF THE BODHI FIG TREE (Ficus religiosa L. - Moraceae)
} IN BRAZIL

\author{
NATURALIZAÇÃO DA FIGUEIRA-DOS-PAGODES (Ficus religiosa L. - Moraceae) \\ NO BRASIL
}

\author{
Marcelo Dias Machado VIANNA-FILHO ${ }^{1}$; Ruy José Válka ALVES ${ }^{1}$; Yan-Qiong PENG ${ }^{2}$; \\ Rodrigo Augusto Santinelo PEREIRA ${ }^{3}$ \\ 1. Department of Botany, Museu Nacional, Rio de Janeiro, Brazil; 2. Key Laboratory of Tropical Forest Ecology, Xishuangbanna \\ Tropical Botanical Garden, China Academy of Sciences, Kunming, China; 3. Department of Biology, FFCLRP, University of Sao \\ Paulo, Ribeirão Preto, Brazil. raspereira@yahoo.com.br.
}

\begin{abstract}
Ficus religiosa $\mathrm{L}$. is one of the most valued cultivated ornamental fig trees. Native to Asia, it is known as Bodhi tree. Since fig trees are involved in a highly species-specific pollination mutualism with agaonid wasps, exotic fig species usually fail to produce seeds due to the lack of the specific pollinating wasps. Since 2005 we have been observing plantlets of $F$. religiosa growing on buildings in Rio de Janeiro city, Brazil, showing that this species was hosting pollinating wasps and, consequently, undertaking sexual reproduction outside its native range. We observed that Platyscapa quadraticeps Mayr, 1885, the original pollinator in Asia, was occurring in figs of $F$. religiosa in Brazil. Considering that several non-pollinating fig wasp species are associated with $F$. religiosa in its native areas, novel occurrences of wasps may be reported in the future in Brazil. The presence of the native pollinator provides conditions for this exotic tree to become naturalized and/or invasive in Brazil, potentially causing considerable damage to buildings and urban trees.
\end{abstract}

KEYWORDS: Agaonidae. Alien species. Fig wasp. Mutualism. Pollination.

\section{INTRODUCTION}

There are over 750 species of fig trees (Ficus spp., Moraceae), many of them employed as ornamental plants, especially those of the subgenus Urostigma Miq., the most diverse group in the genus (BERG, 1989). Fig trees have highly adapted inflorescences, defined by an enclosed inflorescence, the syconium, which is also the arena for interactions with fig wasps. Each fig has its own pollinating wasp species (sometimes more than one) from the family Agaonidae, upon which it depends for pollination (COOK; RASPLUS, 2003). Successful biological invasion by a Ficus species thus involves co-invasion by its symbiont pollinator. Generally, fig wasps disperse (or are introduced by man) to an area where their host fig tree has been planted. Therefore, towns and cities may act as centers of establishment for Ficus spp. from outside the area (McPHERSON, 1999).

The Asian fig tree Ficus religiosa L., known as Bodhi tree, is revered by Buddhists because Siddhartha Gautama was enlightened underneath it while in meditation (MULLER, 1999). Around the world, $F$. religiosa has been introduced as an ornamental tree. Specifically in Brazil, it was introduced in the urban landscaping of Rio de Janeiro at the end of the $19^{\text {th }}$ century (CARAUTA; DIAZ, 2003) with other fig species from the Old World (e.g., F. benjamina L., F. microcarpa L., F. lutea Vahl. and F. sycomorus L.). Ficus religiosa is pollinated by Platyscapa quadraticeps Mayr, 1885 in its native range. Its mature figs measure 10-15 $\mathrm{mm}$ in diameter, are red in color, and are dispersed by birds (SHANAHAN et al., 2001). F . religiosa has become naturalized in the United States (Florida), Hong Kong, Israel, South Africa and Zambia because its pollinator was successful in colonizing these areas (GALIL; EISIKOVITCH, 1968; NADEL et al., 1992; CORLETT, 2006; van NOORT et al., 2013). The occurrence of insect galls in flowers of $F$. religiosa has been reported in Brazil since the 1980's, without delving into insect identification (NEVES; ISAIAS, 1987).

Most of the exotic fig trees introduced in urban landscaping do not reproduce sexually due to the lack of their natural pollinators. Ficus microcarpa was the first fig tree to spread naturally in the Neotropical environment (FAIRCHILD, 1938) by the acclimation of its specific pollinator, Eupristina verticillata Waterston, 1921, registered as introduced in North America (NADEL et al., 1992; BOUČEK, 1993), and in the early 1990s, in Brazil (FIGUEIREDO et al., 1995). Non-pollinating fig wasps of $F$. microcarpa were also reported in the Neotropics coincidentally with the arrival of the pollinators Walkerella microcarpae Bouček 1993 (RAMÍREZ; MONTERO, 1988; FIGUEIREDO; MOTTA-JUNIOR, 1993); Philotrypesis emeryi Grandi, 1926, Philotrypesis taiwanensis Chen, 
1999, and Odontofroggatia ishii Wiebes, 1980 (FIGUEIREDO et al., 1995; FARACHE et al., 2009). The new occurrence of these wasp species confirmed the naturalization of $F$. microcarpa in cultivated fig trees in urbanized areas. However, there is still no record of $F$. microcarpa invading natural forests in Brazil.

In this study, we reported the occurrence of Platyscapa quadraticeps in $F$. religiosa fig trees in Rio de Janeiro, Brazil, and the subsequent spread of plantlets of this species on walls, roofs and other urban constructions.

\section{MATERIAL AND METHODS}

We studied introduced fig trees in urban areas because $F$. religiosa has not yet invaded forested habitats. We sampled figs prior to wasp emergence in three $F$. religiosa trees (a total of 138 figs) in Rio de Janeiro city, Rio de Janeiro State, Brazil (22 $\left.59^{\prime} 00^{\prime \prime} \mathrm{S}, 4^{\circ} 13^{\prime} 40^{\prime \prime} \mathrm{W}\right)$, in May and September 2007. Figs were placed in a $500 \mathrm{~mL}$ jar covered with voile cloth for wasp emergence. Wasp identification was based on the taxonomical literature (van NOORT; RASPLUS, 2010) and on comparison to specimens of $P$. quadraticeps collected in the Xishuangbanna Tropical Botanical
Garden, Yunnan, China. Voucher specimens are stored in the RAS Pereira collection, University of Sao Paulo, Ribeirão Preto. The identification of Ficus religiosa was based on published taxonomical keys and original specific descriptions, and its voucher is stored in the herbarium of Museu Nacional (R), Rio de Janeiro, Brazil.

Photos of the fig wasps were taken with a Leica MZ16 stereoscope equipped with a DFC320 digital camera. We used CombineZM software to produce the automontage images.

\section{RESULTS}

Plantlets of $F$. religiosa have been found on walls, roofs and other urban constructions in Rio de Janeiro city, Brazil (Figure 1). Pollinating agaonid Platyscapa quadraticeps wasps (Figure 2), the original pollinators of $F$. religiosa in Asia, emerged from all fig samples at the site under study. The occurrence of these wasps confirms the naturalization of $F$. religiosa in urbanized areas. However, there is still no record of $F$. religiosa invading natural forests in Brazil. In addition, plantlets of $F$. religiosa growing naturally in urban areas have been observed in São Paulo city, Brazil (AFP Machado, unpublished data).

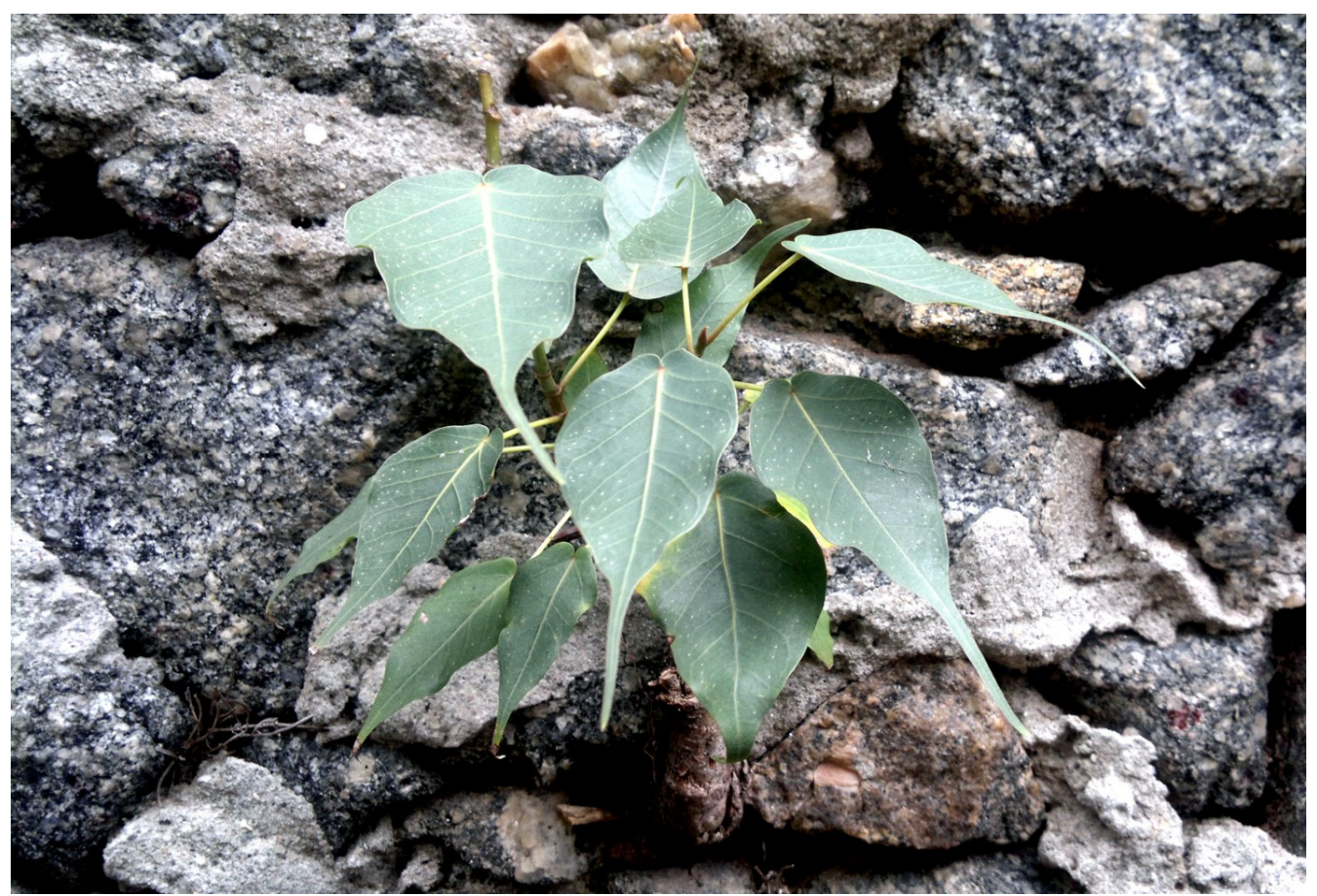

Figure 1. Plantlets of Ficus religiosa L. sprouting through a wall in Rio de Janeiro. 


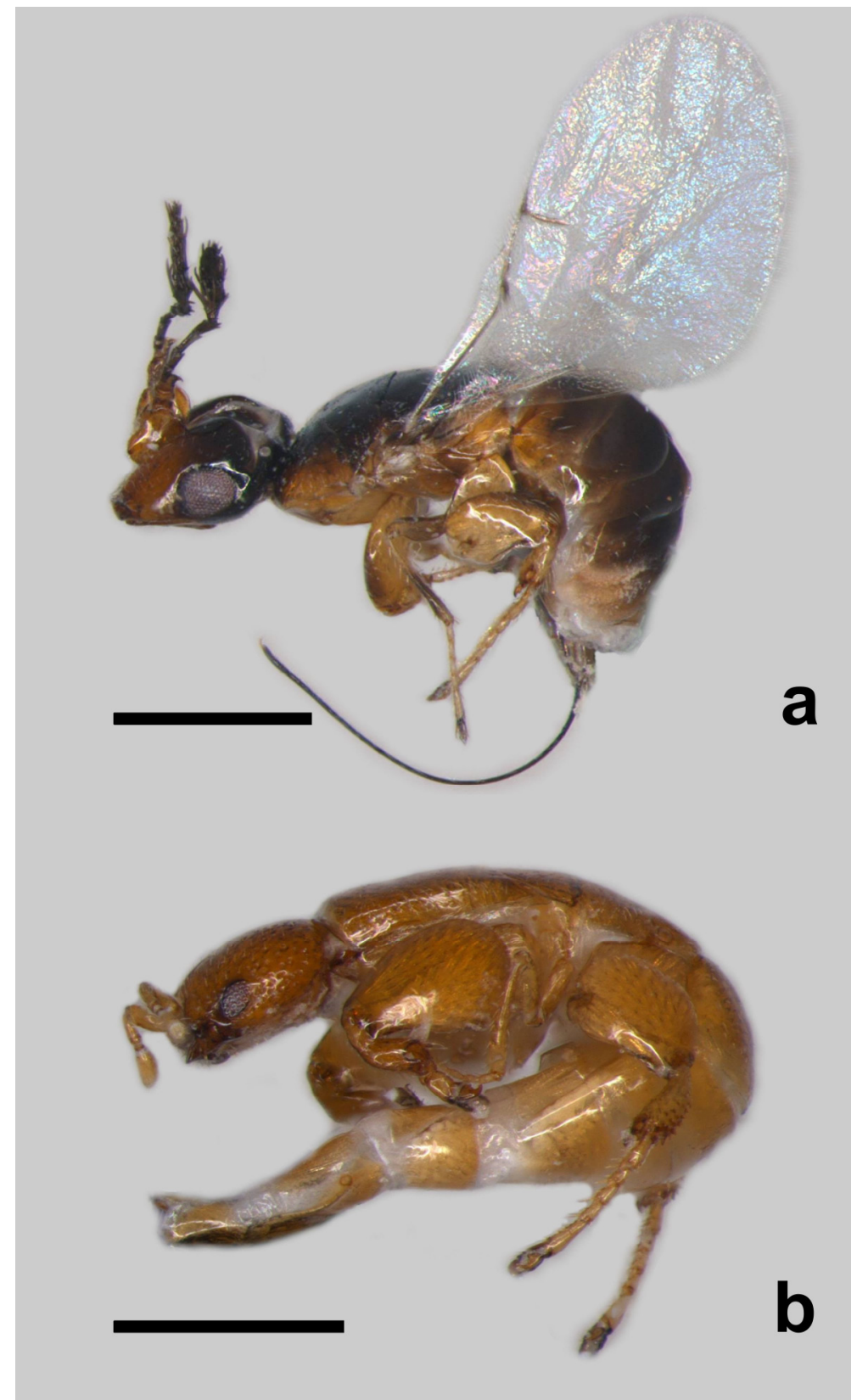

Figure 2. Specimens of Platyscapa quadraticeps Mayr, 1885 collected from Ficus religiosa L. in Brazil, (a) female, (b) male. Scale bar $=0.5 \mathrm{~mm}$.

\section{DISCUSSION}

Ficus religiosa has been introduced in various locations throughout Africa, Australia/Pacific region, North America, Europe, South America and the Middle East as an ornamental tree. Where the specific pollinating wasp is not present, $F$. religiosa has been propagated through cuttings. However, the agaonid pollinator is present in the United States (Florida), Hong Kong, Israel, South Africa and Zambia and $F$. religiosa reproduces sexually through seeds (GALIL; EISIKOVITCH, 1968; PIATOS, 1975; NADEL et al., 1992; CORLETT, 2006; van
NOORT et al., 2013). Plantlets of $F$. religiosa were observed in 2006 growing spontaneously on walls in Santo Domingo city, Dominican Republic, Central America (RAS Pereira, unpublished data), indicating that the species is reproducing sexually in this area. Additionally, P. quadraticeps has been reported in Iraq and the United Arab Emirates, but no further information about $F$. religiosa reproduction is available (van NOORT; RASPLUS, 2010). Our results suggest that $P$. quadraticeps has recently arrived in Brazil, because it was only recently that seeds were registered in syconia and juvenile trees have been found on many urban walls and rooftops, often more than $1 \mathrm{~km}$ away from adult 
$F$. religiosa trees. Considering the reports of $F$. religiosa plantlets in the 1970-1980's in Florida and in the 2000's in the Dominican Republic, $P$. quadraticeps was probably introduced in Brazil via North and Central America. Thus, the model of $F$. religiosa naturalization seems to be similar to that reported for $F$. microcarpa in the Americas (NADEL et al., 1992; FARACHE et al., 2009). Indeed, Ficus religiosa pollinators very probably have followed their host species outside their native range, as reported for $F$. microcarpa (WANG et al., 2015). However, in contrast to the naturalization of $F$. microcarpa, the pollinator was the first species to arrive in $F$. religiosa in Brazil, whereas nonpollinating fig wasp species were the first colonizers of $F$. microcarpa trees (FIGUEIREDO et al., 1995). This difference in colonization and the wide range of non-pollinating fig wasps introduced with $F$. microcarpa suggest that the introduction of $F$. religiosa and $F$. microcarpa in the Neotropics followed different patterns. The fact that nonpollinating fig wasp species have not been reported in F. religiosa in the Neotropics (although many species do occur in its native range) could indicate that its plants were transported by man without their figs, and consequently without the wasps they contain. The pollinator $P$. quadraticeps, in contrast, followed their host trees probably due to the exceptional ability of pollinating fig wasps to disperse over long distances carried by the wind (AHMED et al., 2009).

Taking into account the diversity of fig wasps that inhabit $F$. religiosa figs in their natural distribution (WIEBES, 1966), and the gradual influx of fig wasps in other exotic fig trees (e.g. $F$. microcarpa) in Brazil (FARACHE et al., 2009), new occurrences of non-pollinating fig wasps will probably be reported in the future for $F$. religiosa. On the other hand, the naturalization of both $F$. religiosa and $F$. microcarpa in Brazil shows the importance of monitoring the reproduction of exotic fig trees. The early detection of influx of the original pollinators is crucial for defining management programs aiming to minimize the impact of invasive fig trees, which are difficult to control.

\section{ACKNOWLEDGMENTS}

MDMVF was supported by CNPq (PostDoctoral grant \#160126/2012-6), RJVA by CNPq (grant \#311429/2009-2) , and RASP by Fapesp (grant \#04/10299-4) and $\mathrm{CNPq}$ (grant \#306078/2014-7). We thanks Elettra Greene for the English revision.

RESUMO: Ficus religiosa L. é uma das figueiras ornamentais mais valorizadas. Nativa da Ásia, é conhecida popularmente como figueira-dos-pagodes. Como as figueiras apresentam um mutualismo especializado com vespas Agaonidae as espécies exóticas geralmente não se reproduzem sexualmente devido a falta dos polinizadores específicos. Desde 2005 nós observamos plantas jovens de F. religiosa crescendo sobre construções na cidade do Rio de Janeiro, Brasil, indicando que esta espécie está interagindo com vespas polinizadoras e, consequentemente, se reproduzindo sexualmente fora de sua área nativa. Observamos que Platyscapa quadraticeps Mayr, 1885, o polinizador original na Ásia, estava ocorrendo em figos dessa espécie no Brasil. Considerando que várias espécies não-polinizadoras de vespas de figo são associadas a $F$. religiosa em suas áreas nativas, novas ocorrências de vespas podem ser relatadas no futuro no Brasil. A presença do polinizador nativo provem condições para que esta espécie exótica se naturalize e/ou se torne invasiva no Brasil, com grande potencial de causar danos em prédios e árvores urbanos.

PALAVRAS-CHAVE: Agaonidae. Espécies invasoras. Mutualismo. Polinização. Vespa de figo.

\section{REFERENCES}

AHMED, S.; COMPTON, S. G.; BUTLIN, R. K.; GILMARTIN, P. M. Wind-borne insects mediate directional pollen transfer between desert fig trees 160 kilometers apart. Proceedings of the National Academy of Sciences, Washington, v. 106, n. 48, p. 20342-20347, dec. 2009. https://doi.org/10.1073/pnas.0902213106

BERG, C. C. Classification and distribution of Ficus. Experientia, Basel, v. 45, n. 7, p. 605-611, jul. 1989. https://doi.org/10.1007/BF01975677

BOUČEK, Z. The genera of chalcidoid wasps from Ficus fruit in the New World. Journal of Natural History, Colchester, v. 27, n. 1, p. 173-217, 1993. https://doi.org/10.1080/00222939300770071 
CARAUTA, J. P. P.; DIAZ, E. B. Figueiras no Brasil. Rio de janeiro: Editora da Universidade Federal do Rio de Janeiro, 2002. 211 p.

COOK, J. M.; RASPLUS, J. Y. Mutualists with attitude: coevolving fig wasps and figs. Trends in Ecology and Evolution, Maryland Heights, v. 18, n. 5, p. 241-248, may. 2003.

CORLETT, R. T. Figs (Ficus, Moraceae) in urban Hong Kong, south China. Biotropica, v. 38, n. 1, p. 116121 , jan. 2006.

FAIRCHILD, D. The world was my garden: travels of a plant explorer. New York: Charles Scribner's Sons, 1938. $494 \mathrm{p}$.

FARACHE, F. H. A.; Ó, V. T.; PEREIRA, R. A. S. New occurrence of non-pollinating fig wasps (Hymenoptera: Chalcidoidea) in Ficus microcarpa in Brazil. Neotropical Entomology, Londrina, v. 38, n. 5, p. 683-685, sept-oct. 2009. https://doi.org/10.1590/S1519-566X2009000500020

FIGUEIREDO, R. A.; MOTTA-JUNIOR, J. C. Biology of Walkerella yashiroi (Ishii) (Hymenoptera, Chalcidoidea). Naturalia, Rio Claro, v. 18, p. 27-32, 1993.

FIGUEIREDO, R. A.; MOTTA-JUNIOR, J. C.; VASCONCELLOS, L. A. S. Pollination, seed dispersal, seed germination and establishment of seedlings of Ficus microcarpa, Moraceae, in southeastern Brazil. Revista Brasileira de Biologia, São Carlos, v. 55, n. 2, p. 233-239, 1995.

GALIL, J.; EISIKOWITCH, D. On the pollination ecology of Ficus religiosa in Israel. Phytomorphology, Delhi, v. 18, n. 3, p. 356-363, sept. 1968.

McPHERSON, J. R. Studies in urban ecology: strangler figs in the urban parklands of Brisbane, Queensland, Australia. Australian Geographical Studies, Australia, v. 37, n. 3, p. 214-229, nov. 1999.

https://doi.org/10.1111/1467-8470.00080

MULLER, C. The Sutra of perfect enlightenment. Albany: State University of New York, 1999. 250 p.

NADEL, H.; FRANK, J. H.; KNIGHT-Jr, R. J. Escapees and accomplices: the naturalization of exotic Ficus and their associated faunas in Florida. Florida Entomologist, Lutz, v. 75, n.1, p. 29-38, mar. 1992. https://doi.org/10.2307/3495478

NEVES, L. J.; ISAIAS, R. M. S. Ocorrência de agente galhador em flores de Ficus religiosa L.f. Bradea, Rio de Janeiro, v. 4, n. 40, p. 327-330, mar. 1987.

PIATOS, P. Seed production in an exotic Ficus species. Proceedings of the Florida State Horticultural Society, Lake Alfred, v. 88, p. 462-464, nov. 1975.

RAMÍREZ, W.; MONTERO, J. Ficus religiosa L., F. benjamina L. and other species introduced in the New World, their pollinators (Agaonidae) and other fig wasps. Revista de Biologia Tropical, San José, v. 36, n. 2B, p. 441-446, 1988.

SHANAHAN, M.; SO, S.; COMPTON, S. G.; CORLETT, R. Fig-eating by vertebrate frugivores: a global review. Biological Reviews of the Cambridge Philosophical Society, v. 76, n. 4, p. 529-572, nov. 2001. https://doi.org/10.1017/S1464793101005760

van NOORT, S.; RASPLUS, J. Y. Order Hymenoptera, Chalcidoidea associated with figs (families Agaonidae and Pteromalidae). In: van HARTEN, A. (Ed.). Arthropod fauna of the UAE, Volume 3. Abu Dhabi: Dar Al Ummah Printing, Publishing, Distribution \& Adver-tising, 2010. p. 25-355. 
van NOORT, S.; WANG, R.; COMPTON, S. G. Fig wasps (Hymenoptera, Chalcidoidea: Agaonidae, Pteromalidae) associated with Asian fig trees (Ficus, Moraceae) in Southern Africa: Asian followers and African colonists. African Invertebrates, KwaZulu-Natal, v. 54, n. 2, p. 381-400, sept. 2013. https://doi.org/10.5733/afin.054.0208

WANG, R.; AYLWIN, R.; BARWELL, L.; CHEN, X. Y.; CHEN, Y.; CHOU, L. S.; COBB, J.; COLLETTE, D.; CRAINE, L.; GIBLIN-DAVIS, R.M.; GHANA, S. HARPER, M.; HARRISON, R. D.; McPHERSON, J. R.; PENG, Y. Q.; PEREIRA, R. A. S.; REYES-BETANCORT, A.; RODRIGUEZ, L. J.; STRANGE, E.; van NOORT, S.; YANG, H. W.; YU, H.; COMPTON, S. G. The fig wasp followers and colonists of a widelyintroduced fig tree, Ficus microcarpa. Insect Conservation and Diversity, v. 8, n. 4, p. 322-336, jul. 2015. https://doi.org/10.1111/icad.12111

WIEBES, J. T. Provisional host catalogue of Fig wasps (Hymenoptera, Chalcidoidea). Zoologische Verhandelingen, Leiden, v. 83, p. 1-44, 1966. 